


\title{
23. Dancing in Stone Circles
}

\section{Author(s): A. L. Lewis}

Source: Man, Vol. 15 (1915), pp. 39-40

Published by: Royal Anthropological Institute of Great Britain and Ireland

Stable URL: http://www.jstor.org/stable/2788400

Accessed: 27-06-2016 09:06 UTC

Your use of the JSTOR archive indicates your acceptance of the Terms \& Conditions of Use, available at

http://about.jstor.org/terms

JSTOR is a not-for-profit service that helps scholars, researchers, and students discover, use, and build upon a wide range of content in a trusted digital archive. We use information technology and tools to increase productivity and facilitate new forms of scholarship. For more information about JSTOR, please contact support@jstor.org.

Wiley, Royal Anthropological Institute of Great Britain and Ireland are collaborating with JSTOR to digitize, preserve and extend access to Man 
Balūchistān. By Denys Bray.

on the Balüchistān Census Report, 1911, suggest that the following note on the Brāhūī awe of North and South may be of some interest.

Direction is a very vital matter to the Brāhūī. His fundamental rule (as I have described elsewhere ${ }^{*}$ ) is never to go in the ever-shifting direction of the star. But as he has devised various ways of getting round it, his actions are probably more cramped in reality by the awe that North and West inspire in him.

He will never sleep with his feet to North or West. Still less would he dream of spitting towards either. He regards it as the height of folly to build a house facing North or West, for this would necessitate his turning his back on the revered direction as he entered. He would much prefer to have nothing to do with any water-whether natural spring, water-cut, or subterranean kärēz-which runs East or South from its source, for water that turns its back on the revered direction must clearly be unlucky. Innumerable instances of disasters befalling those who have broken the last two of these very simple rules-I gather that the first two are never broken-are cited as awful warnings, and the fact that there are hundreds of $k \bar{a} r \bar{e} z$ in the Brāhūī country which run from East to West and from South to North, whereas it would apparently be difficult to count half-a-dozen that ran in the contrary directions, was mentioned to me as a proof not merely of the potency of the belief itself, but also of the impossibility of water which tried to run in an unnatural direction continuing to run long.

Mecca, of course, lies West of Balūchistān and due North, so wise Brāhūī tell me, lies the holy shrine of the great saint of Baghdād. Despite the attractiveness of the idea that the particular direction held sacred by a people indicates the direction from which they came to the country, I very much doubt whether we have here any clue to the riddle of the presence of the Dravidian-speaking Brāhūi in Balūchistān.

DENYS BRAY.

\section{Folklore.}

Dancing in stone Circles. By A. L. Lewis.

During the discussion on Mr. Allen Upward's paper on the "Magical $2 \mathbf{6}$ Siege of Troy," Mr. Hodson gave an interesting account of a ceremonial dance by natives at a stone circle discovered by him in India. Another speaker suggested the possibility of such dances having taken place at Stonehenge ; Geoffrey, of Monmouth, certainly spoke of Stonehenge as "the Giants' Dance," but the interior of the circles would not have been a very convenient place for dancing. Dance Maen, in Cornwall, has also the name of "Merry Maidens," from the tradition that the 19 stones composing the circle were girls turned to stone for dancing on Sunday, and two large menhirs to the north-east, not now, if ever, visible from the circle, are supposed to have been the "Pipers" on the occasion; other stones which are nearer the circle are not, however, included in the legend. The much larger circles at Stanton Drew (Somersetshire) have been called the "Stone Wedding," the tale being that the stones were a wedding party which danced all through a Saturday night, but became stenes when the first rays of the sun fell upon them on the Sunday morning, which also happened to be the longest day.

Borlase (Dolmens of Ireland, Vol. 2, p. 535) says four oval rings of stones $(21 \times 14$ feet) near Arendorf, in Germany, were called by the natives "Jekkendanz," meaning "Dance of the Geeks," or Silly Folk. In 1882 Sir John Lubbock also reproduced a picture of a native dance in a stone circle in Virginia. The tops of

\footnotetext{
* Balüchistān Census Report, 1911, paragraph 122 ; The Life-history of a Brāhüi. paragraph 240.
} 
these stones were carved to represent heads, in which respect they resemble the Cross River (West Africa) circles described by Mr. Partridge. If there were no other traditions these might suffice to establish the belief that dances of some kind were performed in all the circles, but sometimes the tradition is of soldiers, as at the Roll-rich in Oxfordshire, and in Brittany; or of a wonder-working cow, as at Mitchellsfold, in Shropshire ; or of footballers playing on Sunday, as at the "Hurlers," in Cornwall; so that perhaps the most we can say is that something was probably done in the circles on the weekly day of the sun in pagan times which was not approved by later ecclesiastical authorities. The gentlemen who now go about the country playing at "Druids," and setting up small circles which may mislead archæologists in future years, do not include dancing amongst the ceremonies they claim to have derived from earlier sources; if they could be induced to do so their proceedings would be even more amusing than they are now.

A. L. LEWIS.

\section{Africa, East.}

Beech.

Pre-Bantu Occupants of East Africa. By M. W. H. Beech, M.A.

Apropos of Sir Harvy Johnston's most interesting survey of the Ethnology 24 of Africa and Mr. Emil Torday's remarks thereon in Vol. XLIII (1913) of the Journal, the following note, which I took a year or two ago, just before leaving the Kikuyu country, may perhaps be of interest as showing a Kikuyu tradition concerning the occupation of their country by two pre-Bantu peoples. During a conversation with some A-Kikuyu elders I was informed that in the land they now occupy in the Dagoneta district, which was until quite recently covered with dense forests but is now cleared and cultivated, if they dug down low enough (which they seldom do) they not unfrequently came across pieces of ancient pottery of a workmanship entirely different from their own.

Although I left the district before succeeding in obtaining a piece, all the elders agreed that this pottery was the work of the "Gumba," a people who inhabited the Kikuyu country after displacing a race of cannibal dwarfs called Maithöachiana, and that further information could doubtless be obtained from the elders of the Fort Hall district, whence the present occupiers of Kikuyu had come less (probably) than 100 years ago.

Mr. Northcote, the District Commissioner of Fort Hall, kindly questioned his elders, and sent me the following:-

"The Maithö̈achiana appear to be a variety of earth-gnomes with many of the usual attributes : they are rich, very fierce, very touchy, e.g., if you meet one and ask hirn who his father is he will spear you; or if he asks you where you caught sight of him first, unless you say that you had seen him from afar, he will kill you, the inference being, I suppose, that you have seen what he was doing, burying treasure, \&c. This is only a guess on my part.

"Like earth-gnomes in most folklore, they are skilled in the art of iron-working. They originally lived round this part (i.e., south of Mount Kenia), but they were driven out by another legendary people called the 'Gumba', who dwelt in caves dug in the earth, and who disappeared one night after teaching the Kikuyu the art of smelting. Another account says that they lived in the earth themselves. It is a Kikuyu insult to say 'You are the son of a Maithoachiana.'"

The references might well be to Bushmen, Pygmies, or both, and it is, perhaps, not unreasonable to suppose that the Maithö̆achiana were an indigenous pigmy or bushman race of the Stone Age who made and used the many stone implements which are to be found everywhere in the Kikuyu district. In this case Mr. Northcote's informant may have erroneously attributed to them the skill in iron work which was in reality only possessed by their successors, the Gumba. 